George Brockway: A Remembrance

by

David Colander

June 2003

MIDDLEBURY COLLEGE ECONOMICS DISCUSSION PAPER NO. 03-34

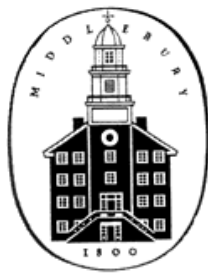

DEPARTMENT OF ECONOMICS

MIDDLEBURY COLLEGE

MIDDLEBURY, VERMONT 05753

http://www.middlebury.edu/ econ 


\title{
George Brockway: A Remembrance
}

\section{By David Colander (Middlebury College and Princeton University)}

\author{
(Written for the Editor's Corner at the JPKE)
}

A number of years ago I got a call from Drake McFeely, the CEO at W. W. Norton and Company. As a favor to him, would I look at a manuscript, see what I think, and offer some suggestions for improving it? He said that although it attacked economists pretty heavily, he thought that I would like it. He went on to say that the manuscript was by George Brockway, a predecessor of his as CEO at Norton Publishers. He told me that he had had it reviewed by other economists but those who had looked at it either had little to say, or what they said had had little effect on George, who was fully aware of the standard economic line, and didn't take much of that mainstream line seriously.

I took a look at the manuscript and liked a lot of it. (Economist-bashing is a passion of mine.) But I am an economist, after all, and have much mainstream blood running in my veins (much to Paul's dismay) and I also wrote that I felt that in a number of places the manuscript didn't show an understanding of economic thinking. I also felt that, in a couple of places, it was not as fair to economists as it might be.

Upon receiving the review, Drake asked if he could pass my name on to George, in the hope of encouraging him to take the comments more seriously than he had taken previous reviews-after all, they were by a fellow economist-basher--and I said, sure. He did so, and not long thereafter I received a letter from George explaining why, although he respected me and my writings, he was not taking the majority of my comments into account. That letter began a warm friendship.

I had George up to Middlebury to lecture to students a couple of times, which gave me a chance to talk with him. He also gave me a subscription to the New Leader, for which he wrote a column entitled "The Dismal Science." Over the years, he kept his latest manuscripts passing over my desk, and sent me drafts and finished copies of his various books, including the two best known to economists: Economists Can be Dangerous for Your Health, and The End of Economic Man. All were beautifully written, and well argued. (Bob Heilbroner, one of the best writers in the profession, had this to say about him: "George Brockway is a master at demystifying the science whose curse is not that it is dismal, but that it has become incomprehensible. In Brockway's hands economics becomes entirely understandable, sometimes amusing, and often infuriating.") 
I responded to all of George's letters, taking essentially the position that I had in my first review of his work. He kept disregarding anything I had to say that defended mainstream economists. It was a foundation for an excellent friendship.

I liked George a lot, perhaps because I see myself as a liberal arts professor, and George was the ideal liberal arts student. He could talk intelligently about almost any subject. He could speak knowledgably and urbanely on a variety of topics, and was a superb conversationalist. His reading in economics was phenomenal. He could quote from Adam Smith, or Karl Marx, unlike the majority of economists today, and he also kept up with modern developments in economics. He viewed economists with a dispassionate, curious wonderment. "Could they really believe the things they were saying?” Although he had made Norton Publishers a center of economic publishing, he thought most economists often lacked humaneness and kindness, a view I shared with him. Thus, it is not surprising that he was attracted to heterodox economists, especially post-Keynesians, who shared with him a sensibility about what is reasonable economics, a generally liberal policy commitment, and a distain for much of mainstream economics.

Two aspects of modern economics got George's dander up most: (1) Its belief in the existence of a natural rate of unemployment, and (2) Its view that tightening monetary policy and raising interest rates would somehow lower inflation. On the first issue I agreed with him completely, and it is interesting to see how, after policy discussions of the 1990s were almost totally centered around a concept of the NAIRU, that the new discussion of policy has pushed any discussion of the NAIRU aside, I think in the hope that no one will look at how policy was centered on it in the past. (Of course, it has simply been replaced by a growth constant, with as little justification as the NAIRU, but that's another story.) On the second issue, I agreed with him halfway. He argued that interest is a cost-raising interest rates raises costs and thereby raises prices. That view is, of course, quite right, and standard economics does not adequately take that into account.

Where I parted company with George is in the indirect effects of tight money on inflation. Unlike George, I saw an indirect and none-too-clean connection between tight monetary policy and falling inflation. Sufficiently tight monetary policy would cause enough pain and unemployment to eventually end inflation, if politically the tight monetary policy could be maintained. I fully accepted that it was neither an efficient nor a humane policy. But I argued that it was a policy that could work. He was not willing to credit tight monetary policy with that; for George tight monetary policy-raising interest rates to fight inflation-- was just stupid policy, showing economists' lack of understanding about how the economy works.

That topic continually came up in our conversations, and one evening I think I got to the root of his hatred of high interest rates and tight monetary policy. Norton Publishers had been enormously squeezed by the interest rate rises in the early 1980s; banks wouldn't extend loans, and when Norton Publishers could get loans they were at interest rates that almost sunk the company. Carrying costs of inventory had been pushed up dramatically, and the only answer was to raise prices. He continually saw tight 
monetary policy through the lens of that experience, and he had a visceral reaction against it.

Our disagreements were always pleasant, and I delighted in having him talk to my students. He would challenge their understanding that they had learned in class and make them think about how the system actually worked. His visits to Middlebury always culminated in a dinner and pleasant conversation about wide ranges of topics. What I will miss most about George is those talks.

During those conversations, I learned much about George's earlier life as a pioneer in the development of the modern publishing industry. George was born in Portland, Maine, where he grew up. He attended Williams College and received a bachelor's degree from Williams in 1936. He was a highly successful student and was the editor of Sketch, the college literary monthly, and was elected to Phi Beta Kappa.

Upon graduating he went to work for the McGraw-Hill Book Company, and he worked there from 1937 to 1942, when he left to join Norton Publishers, which was then a small firm. He joined the Army during the war and was an artillery officer in France and Germany. When he came home, he went to work for Norton Publishers, beginning as a copy editor and salesman, but doing a wide variety of other jobs as well. He rose quickly within the organization.

He moved up fast at Norton Publishers because of his insight and sense of the business. Among other accomplishments, he created the concept of the Norton Anthologies in literature, which served as the foundation for freshman English classes for decades, and which were the model for Norton Anthologies in a number of disciplines. His charm, sensibility, and passion for books also enticed a number of famous authors to Norton. He became W. W. Norton and Company’s president (1958 to 1976) and then chairman from 1976 to 1984, when he retired.

It was during this time that he was instrumental in structuring Norton as a true employee-owned company in which all long-term employees must own shares of stock and must sell them back to the company when they leave. In my view that structure is the greatest monument to George's insight and understanding of how the economic system works. It has kept Norton independent ever since, while almost all other publishing companies have become merged into large conglomerates. That corporate structure has allowed Norton much more freedom than other publishers, owned by big conglomerates, have. In creating that corporate structure George contributed enormously to creating new institutions that furthered progressive thought. It is that type of entrepreneurship that can change society.

As I stated above, George read voraciously, and following economics was his particular passion. He was very much tied into post-Keynesian thought, although he was his own person. In his retirement he wrote books, contributed articles to Challenge, the Journal of Post-Keynesian Economics, and the New York Times. He received the honorary degree Litt.D. from Williams 1982. 
I will miss him enormously; as I am sure will many of the readers of this journal. 